\title{
Cotton pest management practices and the selection of pyrethroid resistance in Anopheles gambiae population in Northern Benin
}

Anges Yadouleton ${ }^{1 *}$, Thibaud Martin², Gil Padonou', Fabrice Chandre ${ }^{3}$, Alex Asidi', Luc Djogbenou', Roch Dabiré5, Rock Aïkpon', Michel Boko ${ }^{6}$, Isabelle Glitho ${ }^{7}$ and Martin Akogbeto ${ }^{1}$

\begin{abstract}
Background: Pyrethroid insecticides, carbamate and organophosphate are the classes of insecticides commonly used in agriculture for crop protection in Benin. Pyrethroids remain the only class of insecticides recommended by the WHO for impregnation of bed nets. Unfortunately, the high level of pyrethroid resistance in Anopheles gambiae s.l., threatens to undermine the success of pyrethroid treated nets. This study focuses on the investigation of agricultural practices in cotton growing areas, and their direct impact on larval populations of An. gambiae in surrounding breeding sites.
\end{abstract}

Methods: The protocol was based on the collection of agro-sociological data where farmers were subjected to semi-structured questionnaires based on the strategies used for crop protection. This was complemented by bioassay tests to assess the susceptibility of malaria vectors to various insecticides. Molecular analysis was performed to characterize the resistance genes and the molecular forms of An. gambiae. Insecticide residues in soil samples from breeding sites were investigated to determine major factors that can inhibit the normal growth of mosquito larvae by exposing susceptible and resistant laboratory strains.

Results: There is a common use by local farmers of mineral fertilizer NPK at $200 \mathrm{~kg} / \mathrm{ha}$ and urea at $50 \mathrm{~kg} / \mathrm{hectare}$ following insecticide treatments in both the Calendar Control Program (CCP) and the Targeted Intermittent Control Program (TICP). By contrast, no chemicals are involved in Biological Program (BP) where farmers use organic and natural fertilizers which include animal excreta.

Susceptibility test results confirmed a high resistance to DDT. Mean mortality of An. gambiae collected from the farms practicing CCP, TICP and BP methods were 33\%, 42\% and 65\% respectively. An. gambiae populations from areas using the CCP and TICP programs showed resistance to permethrin with mortality of $50 \%$ and $58 \%$ respectively. By contrast, bioassay test results of An. gambiae from BP areas gave a high level of susceptibility to permethrin with an average mortality of $94 \%$.

Molecular analysis identified An. gambiae s.S, and An. arabiensis with a high predominance of An. gambiae s.s (90\%). The two molecular forms, $M$ and $S$, were also determined with a high frequency of the $S$ form (96\%).

The $K d r$ gene seemed the main target- site resistance mechanism detected in CCP, TICP, and BP areas at the rates ranging from 32 to $78 \%$. The frequency of ace- $1 R$ gene was very low $(<0.1)$.

The presence of inhibiting factors in soil samples under insecticide treatments were found and affected negatively in delaying the development of An. gambiae larval populations.

Conclusions: This research shows that $K d r$ has spread widely in An. gambiae, mainly in CCP and TICP areas where pyrethroids are extensively used. To reduce the negative impact of pesticides use in cotton crop protection, the application of BP-like programs, which do not appear to select for vector resistance would be useful. These results

\footnotetext{
* Correspondence: anges33@yahoo.fr

'Centre de Recherche Entomologique de Cotonou (CREC), 06 BP 2604

Cotonou, République du Bénin

Full list of author information is available at the end of the article
} 


\section{Background}

Malaria remains a major public health problem in Africa. It is reported to be the most significant cause of morbidity and mortality, resulting in a critical loss of working days [1].

More than 2 billion people in the world are at risk of contracting malaria and one million deaths are recorded yearly of which $90 \%$ occur in Sub-Saharan Africa [1]. In Benin, malaria is still the most important disease leading to $67 \%$ consultations in local health centres [2]. The strategy of the National Malaria Control Programme (NMCP) is based on effective case management and vector control with Insecticide-Treated Nets (ITN) and Indoor Residual Spraying (IRS).The development of new insecticides for public health use is limited and requires enormous capital and time, making industry reluctant to embark on such ventures. Novel compounds or alternatives are to be sought in the agricultural pesticide pipeline. Several reports have recently shown evidence that the main African malaria vector, Anopheles gambiae s.l., has developed a high level of resistance to pyrethroid insecticides as well as to other classes of public health insecticides. While resistance is now spreading throughout Sub-Saharan Africa, reports from Benin and the West African region indicated the highest recorded frequencies of the resistance genes [3-6].

The development of pyrethroid resistance in the primary malaria vectors, An. gambiae s.l. and An. funestus [7] is a serious concern. In the last decade, the emergence of resistance in populations of $A n$. gambiae to common classes of insecticides used in public health has been reported in many African countries including Kenya [8], Côte d'Ivoire [9], Benin [10-14], Niger [15], Burkina Faso [16,17], Mali [18], Nigeria [19], South Africa [20], and Cameroun [21]. In the 1960s, the role of selective treatment with organochlorines (OC) in agriculture on resistance of $A n$. gambiae was observed in Mali [22]. Evidence of an association between agricultural use of insecticides and the emergence of resistance in malaria vectors has been repeatedly reported. In Côte d'Ivoire and Burkina Faso, N'Guessan et al. [23] reported that the level of vector resistance to pyrethroid insecticides increased during the cotton growing season. Higher frequencies of $k d r$ alleles were observed in the more intensely farmed cotton production areas of Côte d'Ivoire [9]. In Bukina-Faso, a survey of $k d r$ alleles in An. gambiae field populations showed also a higher frequency of $k d r$ alleles in older cotton areas with a decreasing gradient to non treated areas [17].
Cotton crop protection represents $90 \%$ of the insecticide use in West Africa. The control strategies implemented against cotton pest especially Helicoverpa armigera required a regular repeated applications of insecticides during the cotton plant growing cycle. As recommended by the Institut National des Recherches Agronomiques du Benin (INRAB), six consecutive treatments are applied at two weeks interval to protect the crop against bollworms, leafworms and sucking pests. These insecticides are essentially composed of pyrethroids (PYs), organophosphates (OPs) which are also the main classes used in public health and a cyclodiene. The majority of cotton farms observed in northern Benin are located in the upland landscape while the lowland covers the major mosquito breeding sites. Thus run-off has been assumed to be the mechanism by which insecticides from agricultural sites reach malaria vector breeding sites, where they exert a huge selection pressure on larval stages of $A n$. gambiae s.l. The main malaria vector $A n$. gambiae breeds in puddles, stagnant pools and various sites around or within the lowland. During the rainy season, insecticide residues are washed downwards into mosquito breeding sites thus affecting larval population [24]. According to Akogbeto et al. [25] in Benin, insecticide treatments against cotton pests are applied twice a month, for a timeframe of three consecutive months (between July and October) each year. These treatment periods coincide with the rainy season and correspond to the period of high mosquito densities. The evidence supports the hypothesis that breeding sites contamination is the result of the coincidence of agricultural pesticide application and seasonal rainfall/ runoff.

Alternatively, integrated pest and vector management (IPVM) strategies based on the rational use of chemical protection, has undoubtedly reduced the negative impact of pesticides on humans, and their environment, including the breeding sites of malaria vectors.

This study aimed to assess the impact of control strategies used against cotton pests (relative amount of insecticide) on the frequency and spread of insecticide resistance in $A n$. gambiae populations. The study, conducted in northern Benin, compared the BP cotton cultivation sites (absence of pesticides use) with the CCP and TICP cotton cultivation sites where insecticides are extensively used. The study focused on the investigation of agricultural practices using pesticides for the control of cotton pests and their impact on the insecticide 
susceptibility of An. gambiae populations from surrounding breeding sites.

\section{Methods}

\section{Cotton pests control strategies}

Three pest management and control strategies are officially recommended in Benin:

(1) The Calendar Control Program (CCP) is based on the conventional treatment which systematically uses the full dosage of insecticides.

(2) The Targeted Intermittent Control Program (TICP) is based on two steps of crop protection $[26,27]$. The first steps is a protection which follows a conventional pesticide application schedule (every 14 days from the appearance of floral organs), but only the half dose of insecticide are usually applied. The second step includes a modification of the first treatment meaning that the half-dose left over during the earlier observation made the day before treatment would suggest that the pest populations exceed the economic thresholds of damage. The program was established five years ago.

(3) In the biological control program (BP), no chemical is used for plant protection. That program started over the past five years.

The area of the farms applying CCP and TICP was about 4 hectares and usually farmers ploughed sometime individually or work in groups of farmers' organizations. However, in BP sites of 1 hectare, farmers worked under the supervision of technicians from the Beninese Organization for Organic Farming Promotion (OBEPAP) who assisted in the implementation and the survey of good agricultural practices on organic cotton. These areas were characterised by a continual production of cotton crop.

\section{Study sites}

The study was conducted in the cotton areas around 8 cities in Benin (Figure 1). The choice of these areas took into account the various strategies of pest control. Semi permanent breeding sites were found in cotton fields where farmers used:

- the CCP around Parakou ( $2^{\circ} 62$ E, $\left.9^{\circ} 33 \mathrm{~N}\right)$, Kandi $\left(2^{\circ} 95 \mathrm{E}, 11^{\circ} 16 \mathrm{~N}\right)$ and Banikoara $\left(2^{\circ} 59 \mathrm{E}, 11^{\circ} 31 \mathrm{~N}\right)$. This pest management program started thirty years ago and was the main strategy against pest control used by more than $95 \%$ of the cotton farmers.

- the TICP around N'dali ( $\left.2^{\circ} 70 \mathrm{E}, 9^{\circ} 84 \mathrm{~N}\right)$ ), Kandi ( $3^{\circ} 08 \mathrm{E}$, $\left.11^{\circ} 27 \mathrm{~N}\right)$ and Banikoara $\left(2^{\circ} 41 \mathrm{E}, 1^{\circ} 31 \mathrm{~N}\right)$ started five years ago and applied by $4 \%$ of cotton farmers.

- the BP around Kandi $\left(2^{\circ} 92 \mathrm{E}, 11^{\circ} 09 \mathrm{~N}\right)$ and Banikoara $\left(2^{\circ} 52 \mathrm{E}, 11^{\circ} 29 \mathrm{~N}\right)$ started five years ago and practiced by $1 \%$ of cotton farmers.

The annual mean rainfall recorded was about 1,300 $\mathrm{mm}$ yearly and characterized by a Sudanian climate with one rainy season (middle of May to October) and one dry season (November-May).

\section{KAP Study on the use of insecticides in cotton farms}

To generate adequate information on the use of insecticide on cotton fields, Knowledge Attitude-Practice (KAP) surveys were organized in the study sites. In each site, leaders of farmer's organizations were interviewed using semi-structured questionnaires that focused on the treatment strategies, and the use of insecticides in the farms. Further, qualitative data was collected through direct observations, in-depth interviews and focus group discussions.

\section{Mosquito collections}

Mosquito larvae were collected during the rainy season as well as before and during the period of insecticide treatments. The treatment periods started from July to October. During pest control, insecticide residues contaminate mosquito breeding sites whereby they diffuse into the water applying a selection pressure on mosquito larvae. Larvae were collected in the breeding sites of each site and transported to the laboratory of the Centre de Recherche Entomologique de Cotonou, Benin (CREC) for resistance testing. The adults were tested after emergence. A laboratory susceptible strain of An. gambiae Kisumu was used as a reference strain to compare the susceptibility levels of the field populations.

\section{Insecticide susceptibility tests}

Mosquitoes collected were assayed using WHO discriminating dosages of four insecticides: permethrin $(0.75 \%)$, DDT (4\%), deltamethrin (0.05\%) and bendiocarb (0.1\%). Four batches of 25 unfed females, aged 2-5 days, were exposed to the diagnostic doses of insecticide treated papers for 1 hour. The twenty five females of An. gambiae were introduced into each tube and monitored at different time intervals $(10,15,20,30,45,60$ minutes) the number "knocked-down" recorded. After one hour exposure, mosquitoes were transferred into holding tubes and provided with cotton wools wet with a $10 \%$ honey solution. Mortalities were recorded after 24 hours and the susceptibility status of the population was graded according to the WHO protocol [28]. Dead and surviving mosquitoes from this bioassay were separately kept in Carnoy solution at $-20^{\circ} \mathrm{C}$ for further molecular analysis.

\section{Molecular characterization}

All An. gambiae s.l. were identified to species using PCR [29] and as M and S forms by PCR-RFLP [30]. To detect the presence of $K d r$ mutation in the samples collected from each study site, polymerase chain reaction diagnostic test for detection of $k d r$ "Leu-phe" genes was carried out on An. gambiae mosquitoes from each study site as 


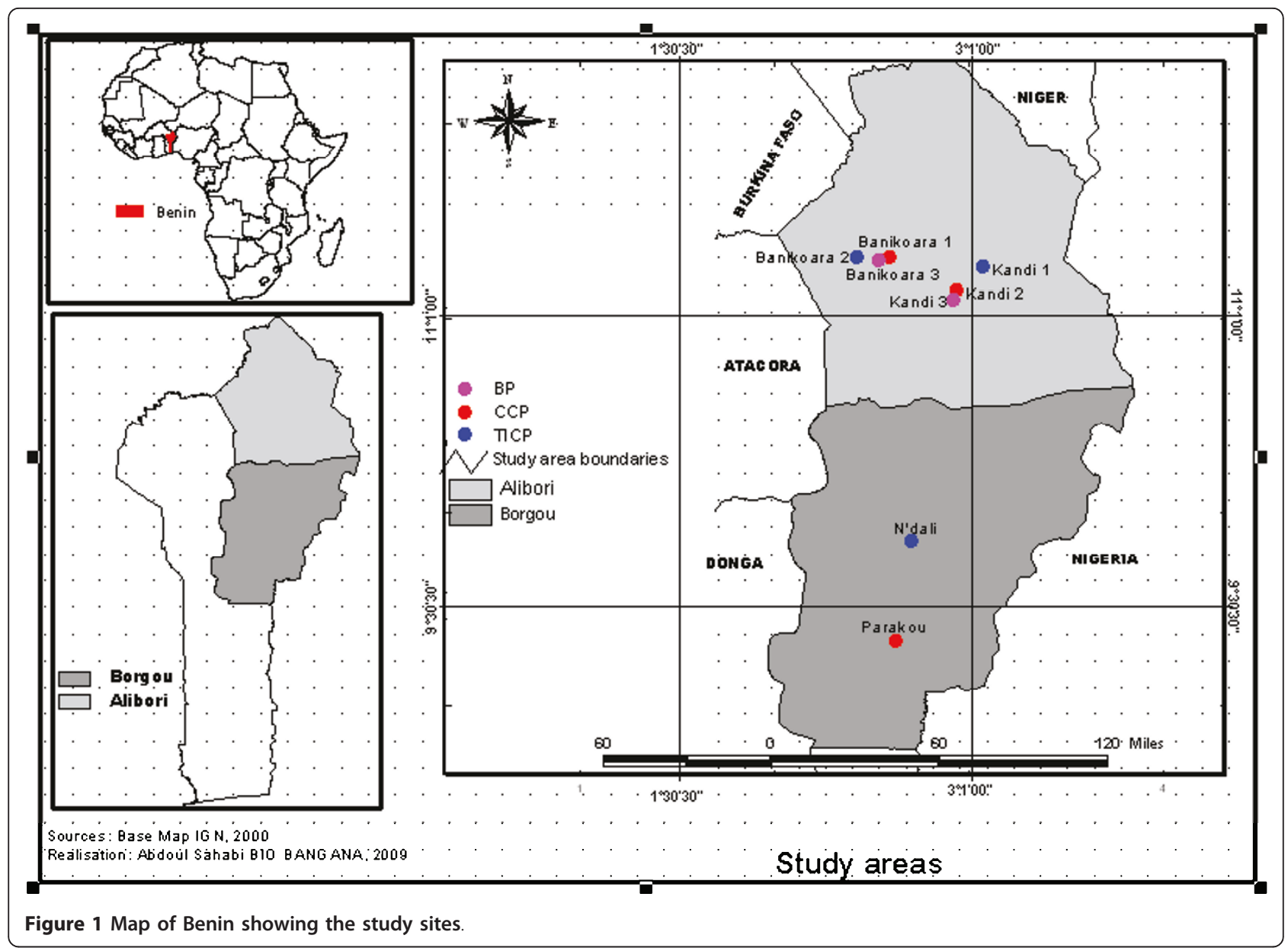

described by Martinez-Torres et al. [31].The PCR-RFLP diagnostic test was used to detect the presence of G119S gene (Ace.1 gene) as described by Weill et al. [32].

\section{Screening of pesticide residues in soil from agricultural settings}

This investigation was performed using indirect bioassays focused on factors which can affect the normal growth of mosquito larvae in cotton breeding sites. The hatching rates of An. gambiae eggs and the larval survival during rearing period were assessed in artificial breeding sites made of soil samples collected from different cotton areas. The pyrethroid-susceptible Kisumu strain and the resistant VKPER strain were used to test the presence of insecticide residues in the soil samples by means of mortality rates after exposure. The testing method was based on an artificial breeding site made of a mixture of soil from cotton sites (BP, TICP and CCP programs) and CREC soil used as a control. $100 \mathrm{~g}$ of each soil was weight and mixed in 1,000 $\mathrm{ml}$ of water. 200 eggs of the susceptible Kisumu strain were placed in each artificial breeding site and compared with 200 eggs of VKPER.
Larvae in all artificial breeding sites were fed with similar quantity and type of food (well ground cat biscuits mixed with yeast powder). Daily observation was done in order to record the number and the instars of larvae. This experiment was replicated three times per month.

\section{Data interpretation}

The resistant status of mosquito samples was determined according to the WHO criteria [33]:

- Mortality rates is > 97\%: the population was considered fully susceptible

- Mortality rates ranged between $80>x<97 \%$ : resistance suspected in the population

- Mortality rates $<80 \%$, the population was considered resistant to the tested insecticides.

The knockdown times for $50 \%$ and $95 \%$ of tested mosquitoes (KdT50 and KdT95) were estimated using a logtime probit model [34].

The resistance allele frequency at the $k d r$ and Ace-1 locus was calculated using Genepop software (version 3.3) as described by Raymond and Rousset [35]. 
A Fisher's exact test was performed to compare the resistance allele frequency at the $k d r$ and Ace-1 among the mosquitoes from the different strategies.

An analysis of variance (ANOVA) was performed to compare the percentage of hatching eggs in the different treatments in order to know the impact of insecticide on the normal growth of mosquito larvae in cotton breeding sites.

\section{Results}

\section{Knowledge-Attitude -Practice (KAP) investigations}

Results from our KAP investigations from June to September 2008 in the cotton growing areas showed a common use by farmers of mineral fertilizer NPK at about $200 \mathrm{~kg} \cdot \mathrm{ha}-1$ and urea at about $50 \mathrm{~kg}$.ha-1 in both the CCP and the TICP sites. By contrast, in BP areas, all farmers in this group used organic and natural fertilizers which included animal excreta. In the CCP sites, about 6 pesticide treatments were applied by farmers 45 days after seeding and at two week intervals from flowering. Endosulfan or Tihan ${ }^{\circledR}$ (mixture of spirotetramat + flubendiamide), were sprayed in the first two treatments followed by the mixtures of cyfluthrin + chlorpyrifos ethyl for the $3^{\text {rd }}$ and the $4^{\text {th }}$ treatment and then cypermethrin + dimethoate applied for the last two treatments. In TICP sites, the same treatments at intervals of two weeks were made either at half dose or at a complete full dosage when the threshold of infestation was reached ( 5 of $H$. armigera larvae observed on 50 plants). In areas practicing Biological Program, farmers apply a mixture of neem or papaya leaves with added chilli and local soap three times before the harvest.

\section{Resistance to insecticides}

A total of 1,313 females of An. gambiae collected from different sites around Parakou, N'dali, Kandi, and Banikoara were exposed to papers impregnated with discriminating doses of permethrin $(0.75 \%)$, deltamethrin (0.05\%), DDT (4\%) and bendiocarb (0.1\%).

The knockdown times (KdT50, KdT95) of An. gambiae populations from CCP and TICP sites were significantly longer than that of the susceptible strain Kisumu ( $\mathrm{p}<$ 0.05). However, the KdT50 for An. gambiae from BP site around Kandi was not significantly different from Kisumu (Table 1). Data recorded before and during the period of treatments showed a higher resistance to DDT and permethrin in populations from the CCP and TICP sites compared with those from the BP sites (Figure 2 and Figure 3). All populations of An. gambiae mosquitoes were resistant to DDT with an average of $33 \%, 42 \%$ and $65 \%$ of mortality respectively for CCP, TICP and BP sites. The mortality difference associated with the different pesticide application strategies was highly significant between $\mathrm{BP}$ and CCP programs $(P<0.05)$ but not significant between $\mathrm{BP}$ and TICP program $(\mathrm{P}=0.56)$. However, An. gambiae populations from BP, CCP and TICP sites were fully susceptible to deltamethrin and bendiocarb (100\% of mortality). Permethrin resistance was found in An. gambiae populations from CCP and TICP sites with an average mortality of $50 \%$ and $58 \%$ respectively. However, An. gambiae collected from BP sites were more susceptible to permethrin with $94 \%$ mortality.

\section{Species identification}

A total of $850 A n$. gambiae adults were analysed for species and molecular forms. Most of the mosquitoes collected from all the sites were An. gambiae s.s. (90\%), which was found in sympatric with a low proportion of An. arabiensis (0 to 5\%) except in Parakou and N'dali where they were more present (22 to $30 \%$ respectively) (Table 2). In An. gambiae s.s, the $\mathrm{M}$ and $\mathrm{S}$ forms were always found in sympatric but the $\mathrm{S}$ form was mostly predominant (96\%).

\section{Resistance mutations}

The $k d r$ genotype was scored for 1,400 individuals (100 mosquitoes consistently failed to amplify). The $k d r$ gene occurred in $\mathrm{S}$ forms (Table 2). The highest frequency of $K d r$ mutation was recorded for the populations from three CCP sites (67-78\%) and the lowest (35 and 32\%) were found in the populations from BP sites around Kandi and Banikora respectively.

The Ace-1R gene was found at very low frequency ranging (from 0.00 to 0.06 ) in heterozygote $A n$. gambiae s.s from the three CCP sites (Table 2). Among An. gambiae s.s, there was no mosquito of the $M$ molecular form carrying the ace-1R gene.

The resistance allele frequency at the $k d r$ was significantly higher in areas where farmers used insecticide for pest control (CCP and TICP) than in those no insecticide is not request $(\mathrm{BP})(\mathrm{p}<0.05$.). However, there is no difference between the resistance allele frequency at the $k d r$ from mosquitoes in CCP and TICP strategies ( $p>0.05$ ).

\section{Pesticide residues}

Results of soil samples for pesticide residues analysis showed that artificial breeding sites made with soil from CREC (control) and soil from Biological program (BP) sites were similar with no effect on hatching of An. gambiae Kisumu and VKPER strains (Figure 4). Tests with the susceptible An. gambiae Kisumu strain gave percentages of hatching equivalent to $80 \%$ in control soil (no contact with pesticides) and $75 \%$ with soil from BP sites. However, with the pyrethroid resistant strain VKPER the percentages of hatching were $83 \%$ and $77 \%$ with the control soil and soil from BP sites respectively. The hatching percentages of both strains decreased significantly when 
Table 1 Knockdown times ( $K d T_{50}$ and $\left.K d T_{95}\right)$ and mortality of Anopheles gambiae s.l. populations from 3 cotton sites after exposure to DDT $4 \%$ and permethrin $0.75 \%$ and their resistance status

\begin{tabular}{|c|c|c|c|c|c|c|c|}
\hline Sites/Strains & Program & Insecticides & $\mathrm{N}$ & kdT50 [Cl95] (min) & kdT95 [Cl95] (min) & \% Mortality [Conf lim 95] & Resistance status \\
\hline & & DDT & 40 & $65.1[57.5-73.4]$ & $152.1[118.4-228.1]$ & 38 [29.31-46.7] & $\mathrm{R}$ \\
\hline \multirow[t]{2}{*}{ Parakou } & CCP & Permethrin & 75 & $35.3[32.1-38.4]$ & $112.1[88.2-151.9]$ & 54 [47.49-60.5] & $\mathrm{R}$ \\
\hline & & DDT & 60 & $38.1[29.4-36.5]$ & $65.1[57.5-86.5]$ & $45[37.73-52.3]$ & $R$ \\
\hline \multirow[t]{2}{*}{ N'dali } & $\mathrm{TICP}$ & Permethrin & 60 & $19.3[15.6-22.4]$ & $67.1[53.2-87.4]$ & $60[52.8-67.16]$ & $\mathrm{R}$ \\
\hline & & DDT & 70 & $63.1[60.2-72.3]$ & $135.1[5.2-184.5]$ & $32[25.7-38.31]$ & $\mathrm{R}$ \\
\hline \multirow[t]{2}{*}{ Kandi1 } & $\mathrm{CCP}$ & Permethrin & 80 & $19.3[15.6-22.4]$ & $87.1[63.5-138.4]$ & 50 [43.67-56.32] & $\mathrm{R}$ \\
\hline & & DDT & 50 & $35.1[27.1-35.2]$ & $62.5[54.2-79.1]$ & $43[35.07-50.92]$ & $\mathrm{R}$ \\
\hline \multirow[t]{2}{*}{ Kandi 2} & $\mathrm{TICP}$ & Permethrin & 88 & $15.1[13.6-20.1]$ & $56.5[43.2-77.2]$ & 58 [52.00-64] & $\mathrm{R}$ \\
\hline & & DDT & 60 & $30.3[25.4-38.9]$ & $72.6[50.2-90.5]$ & $66[59.08-72.92]$ & $R$ \\
\hline \multirow[t]{2}{*}{ Kandi 3} & $\mathrm{BP}$ & Permethrin & 80 & $11.0[8.7-17.6]$ & 23.5 [18.4-35.8] & 94 [91.01-96.98] & $S$ \\
\hline & & DDT & 65 & $56.5[51.7-63.2]$ & $186.9[146.0-265.2]$ & 35 [28.3041.69] & $R$ \\
\hline \multirow[t]{2}{*}{ Banikoara 1} & CCP & Permethrin & 90 & 24.6 [20.3-29.0] & 105.2 [92-130.8] & $51[45.04-56.96]$ & $\mathrm{R}$ \\
\hline & & DDT & 70 & $32.4[25.8-30.2]$ & 60.1 [50.1-78.6] & $41[34.34-47.65]$ & $\mathrm{R}$ \\
\hline \multirow[t]{2}{*}{ Banikoara 2} & $\mathrm{TICP}$ & Permethrin & 70 & 18.5 [16.1-22.4] & $58.1[47.4-78.4]$ & 59 [52.35-65.65] & $\mathrm{R}$ \\
\hline & & DDT & 75 & $29.1[24.4-37.6]$ & $70.1[48.2-88.2]$ & $64[57.73-70.27]$ & $\mathrm{R}$ \\
\hline \multirow[t]{2}{*}{ Banikoara 3} & $\mathrm{BP}$ & Permethrin & 80 & $13.2[9.4-18.2]$ & $25.5[20.2-37.1]$ & 95 [92.24-97.75] & $S$ \\
\hline & & DDT & 100 & $25.7[24.3-27.0]$ & $40.7[38.0-44.5]$ & 98 [96.41-99.58] & $S$ \\
\hline An. gambiae s.l & * & Permethrin & 100 & $10.9[9.7-12.0]$ & $18.1[16.0-21.6]$ & 99 [97.87100.13] & S \\
\hline
\end{tabular}

$K d T_{50}$, knockdown time in min for $50 \%$ mosquitoes; $K d T 95$, knockdown time in min for $95 \%$ mosquitoes; $\mathrm{Cl}$, confidence interval at $95 \%$;

*, No program = Control; Conf Lim 95\% = confidence interval at 95\%.

soil samples from CCP and TICP sites were used. With the TICP soil, VKPER hatching was $45 \%$ against $25 \%$ for the Kisumu strain, whiles the CCP soil gave $34 \%$ hatching for VKPER and $11 \%$ for Kisumu. In both cases the results showed that the hatching rates were significantly higher $(\mathrm{P}<0.05)$ with VKPER than Kisumu when the soil samples tested were from TICP and CCP sites.

Similar results were obtained with the emergence of adults of VKPER and Kisumu strains from eggs placed in artificial breeding sites consisting of water and soil samples from CCP and TICP relative to the control (Figure 4). There was no significant difference between the emergence of adults of VKPER and Kisumu strains breeding in artificial sites made with the soil samples from BP compared with the control (Figure 5).

However, a significant difference $(\mathrm{P}<0.05)$ was observed between the emergence of VKPER on artificial sites made of soils from TICP (43\%) and CCP (35\%) sites and Kisumu which gave $20 \%$ emergence on TICP and $13 \%$ on CCP.

\section{Discussion}

The information generated during interviews with cotton farmers and the observations made in cotton fields has confirmed a common use of fertilizers and insecticides in cotton fields. Cotton cultivation requires intensive use of pesticides including insecticides belonging to the two main classes recommended for vector control in public health: organophosphates and pyrethroids. In
West Africa, pyrethroid-treated bed nets remain one of the effective tools for malaria vector control and it provides personal protection to individuals who sleep under them. When used by the whole community, bed nets protect collectively against infective mosquito bites by a mass killing effect of the vectors [36].

In Benin, pyrethroids have been extensively introduced in agriculture since 1980s [25]. This factor is probably one of the causes of the selection of strong resistance in An. gambiae to permethrin and DDT, particularly in cotton growing areas. Based on recent results, several authors [8-12; 37] have reported that past and current agricultural use of DDT then pyrethroids for crop protection have led to the selection of resistant mosquitoes through insecticide residues accumulated in breeding sites around cotton growing areas. This hypothesis was recently confirmed by Akogbeto et al. [25] showing indirectly the presence of pesticide residues in soil and water from vegetable farms and other agricultural activities in Benin that delay or reduce the emergence rates of mosquito larvae.

The use of insecticides in households for public health purposes and massive quantities of pesticides in agricultural settings has been highlighted as a key factor contributing to the emergence of vector resistance. A recent report by Yadouleton et al.[37] showed that agricultural practices in urban areas seem to have contributed to the emergence of insecticide resistance in Anopheles populations. Our study in vegetable farming systems in Benin 


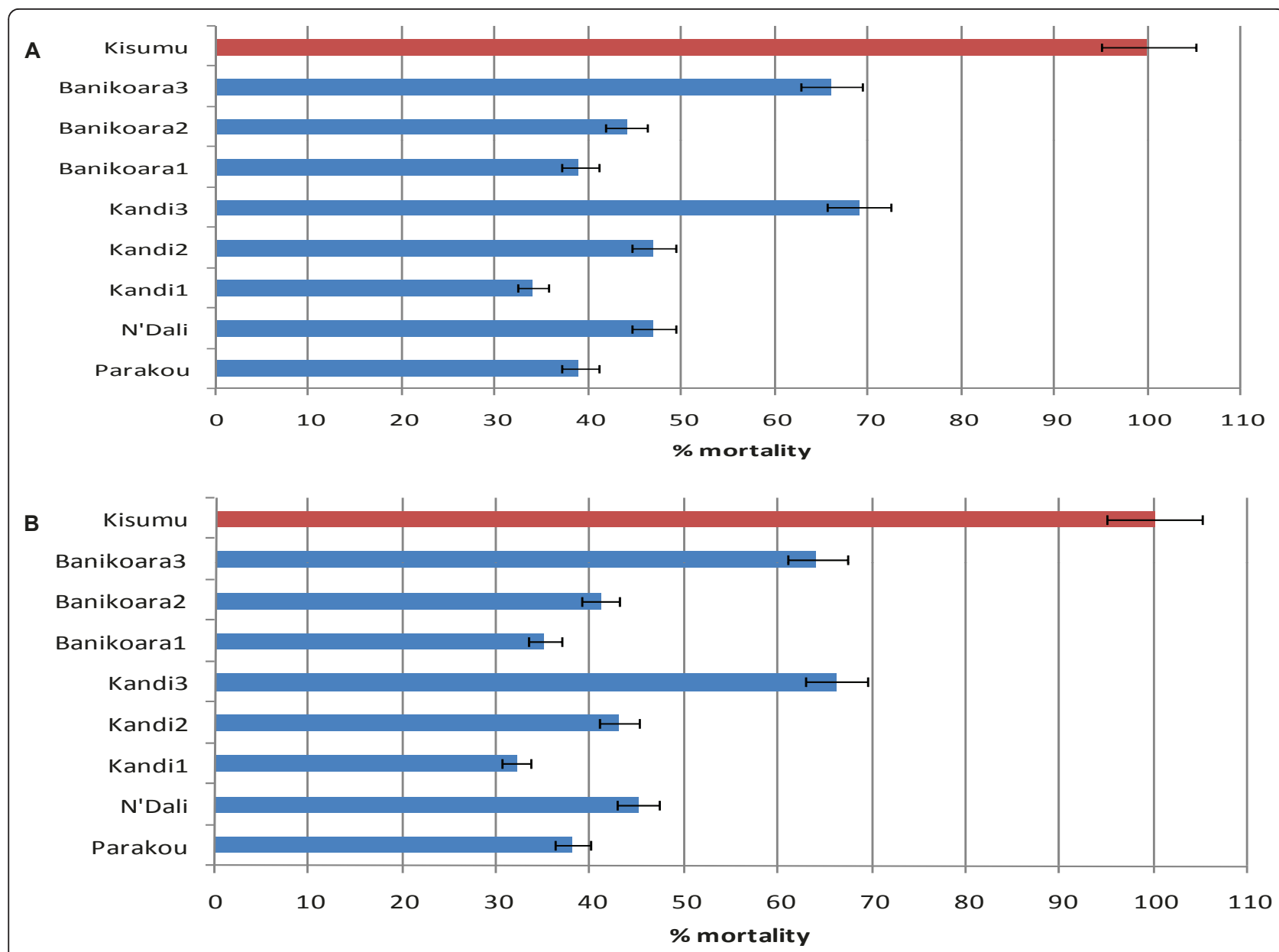

Figure 2 Mortality rates and resistance status of Anopheles gambiae s.l. collected before (A) and after (B) cotton treatments to DDT $4 \%$ using WHO bioassay tests.

demonstrated that improper use of insecticides to control vegetable pests in urban areas directly exerted a huge selection pressure on mosquito larval populations. The high mortality observed with mosquitoes reared on soils from CCP, TICP sites can be explained by the presence of DDT residues in the soil from those sites and the extensive use of pyrethroids by farmers [38]. Our results showed that the high level of the $k d r$-west (Leu-Phe) gene seemed to be the main resistance mechanism and responsible for the decrease of mortality rates to DDT and permethrin and is more of an ongoing process in An. gambiae populations from CCP and TICP sites. The $k d r$ gene in the main malaria vector An. gambiae was found at high frequency in samples from the sites using insecticide (CCP and TICP) than those with no use of insecticide (BP program). The low frequency of $K d r$ gene in BP localities compared with those from CCP and TICP could be due to the fact that in the past these farmers in BP sites used insecticide to control cotton pests. According to reports by Akogbeto et $a l$ [25], Djogbénou et $a l$ [14], and Yadouleton et $a l$. [38], the presence of $K d r$ genes in mosquito can be due to external factors that affect mosquitoes as larvae or adults. In 2000, a study in Burkina Faso by Diabate et $a l$. [17] reported higher levels of $k d r$ alleles frequency in An. gambiae collected from cotton-growing areas constantly subjected to insecticide treatments, as compared to the low frequency of $k d r$ recorded in rural areas where farmers are restricted to low or no use of pesticides. Despite the use of insecticide in both CCP and TICP sites, the difference in adult mortality rates between $\mathrm{CCP}$ and TICP program can be explained by the fact that $\mathrm{CCP}$ program uses more insecticide than TICP program.

This study provides clear evidence of the association between the use of insecticides in agriculture and the widespread emergence of insecticide resistance in Anopheles species.

Indeed, in Benin, insecticide treatments against pests in cotton plantations are carried out twice a month, for 


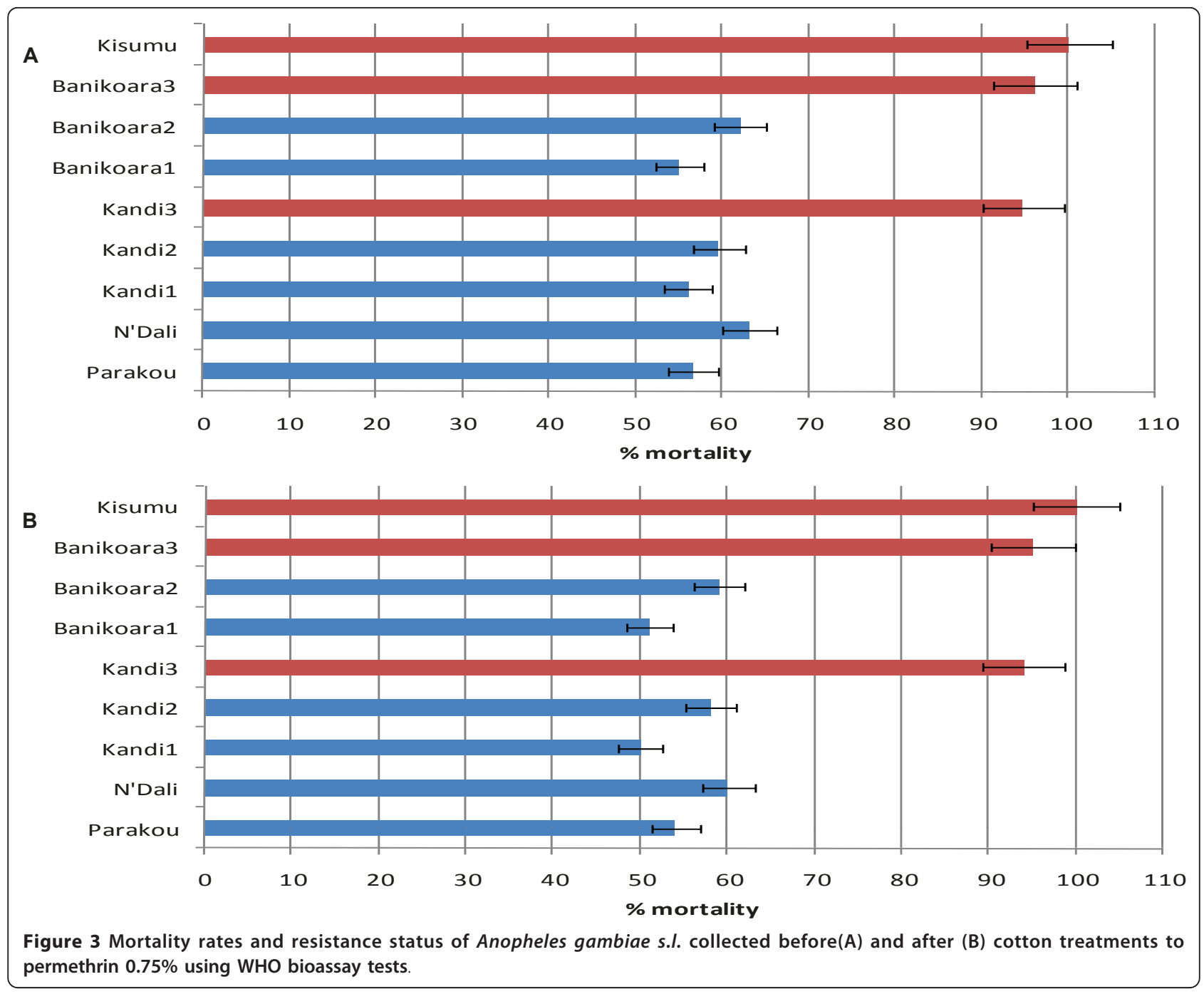

an average period time of three months (between July and October) per year. That treatment period during the rainy season correspond with the period of high mosquito densities because Anopheles populations have numerous breeding sites particularly in cultivated areas.
As reported by Akogbeto et al [26], some populations of An. gambiae may lay their eggs in breeding sites containing insecticide residues. These eggs undergo a selection pressure from agricultural pesticides, which leads to the emergence of resistant strains. There is clear

Table 2 Species and molecular forms identification within Anopheles gambiae complex and the frequency of Kdr and Ace-1R mutations in Anopheles gambiae s.s. in Benin

\begin{tabular}{|c|c|c|c|c|c|c|c|c|c|c|c|c|}
\hline \multirow[b]{2}{*}{ Locality } & \multicolumn{2}{|c|}{ Species $^{a}$} & \multicolumn{2}{|c|}{ Mol. Form } & \multicolumn{2}{|c|}{$K d r$ mutation } & \multirow[b]{2}{*}{ RR } & \multirow[b]{2}{*}{$F(R)$} & \multicolumn{3}{|c|}{ Ace.1 mutation } & \multirow[b]{2}{*}{$F(R)$} \\
\hline & $\% A a$ & $\% A g$ & $\% \mathrm{M}$ & $\% \mathrm{~S}$ & SS & $\mathrm{RS}$ & & & SS & $\mathrm{RS}$ & RR & \\
\hline Parakou $^{1}(92)$ & 22 & 78 & 5 & 95 & 12 & 35 & 45 & 0.68 & 30 & 02 & 0 & 0.06 \\
\hline $\mathrm{N}^{\prime} \mathrm{dali}^{2}(92)$ & 30 & 70 & 3 & 97 & 22 & 40 & 30 & 0.54 & 25 & 0 & 0 & 0.00 \\
\hline Kandi $^{1}(92)$ & 5 & 95 & 0 & 100 & 7 & 45 & 40 & 0.67 & 30 & 02 & 0 & 0,06 \\
\hline Kandi $^{2}(92)$ & 4 & 96 & 0 & 100 & 28 & 34 & 30 & 0.51 & 30 & 01 & 0 & 0.03 \\
\hline $\operatorname{Kandi}^{3}(90)$ & 0 & 100 & 0 & 100 & 45 & 25 & 20 & 0.35 & 30 & 0 & 0 & 0.00 \\
\hline Banikoara $^{1}(102)$ & 3 & 97 & 0 & 100 & 12 & 36 & 54 & 0.78 & 30 & 02 & 0 & 0.06 \\
\hline Banikoara $^{2}(92)$ & 02 & 98 & 0 & 100 & 14 & 48 & 30 & 0.59 & 30 & 0 & 0 & 0.00 \\
\hline Banikoara $^{3}(96)$ & 02 & 98 & 2 & 98 & 48 & 36 & 12 & 0.32 & 25 & 0 & 0 & 0.00 \\
\hline
\end{tabular}

( a) $\mathrm{Aa}=$ An. arabiensis; $\mathrm{Ag}=$ An. gambiae s.S., superscripts in column; $1=$ Control strategies: $1=\mathrm{CCP} ; 2=\mathrm{TICP} ; 3=\mathrm{BP}$. 


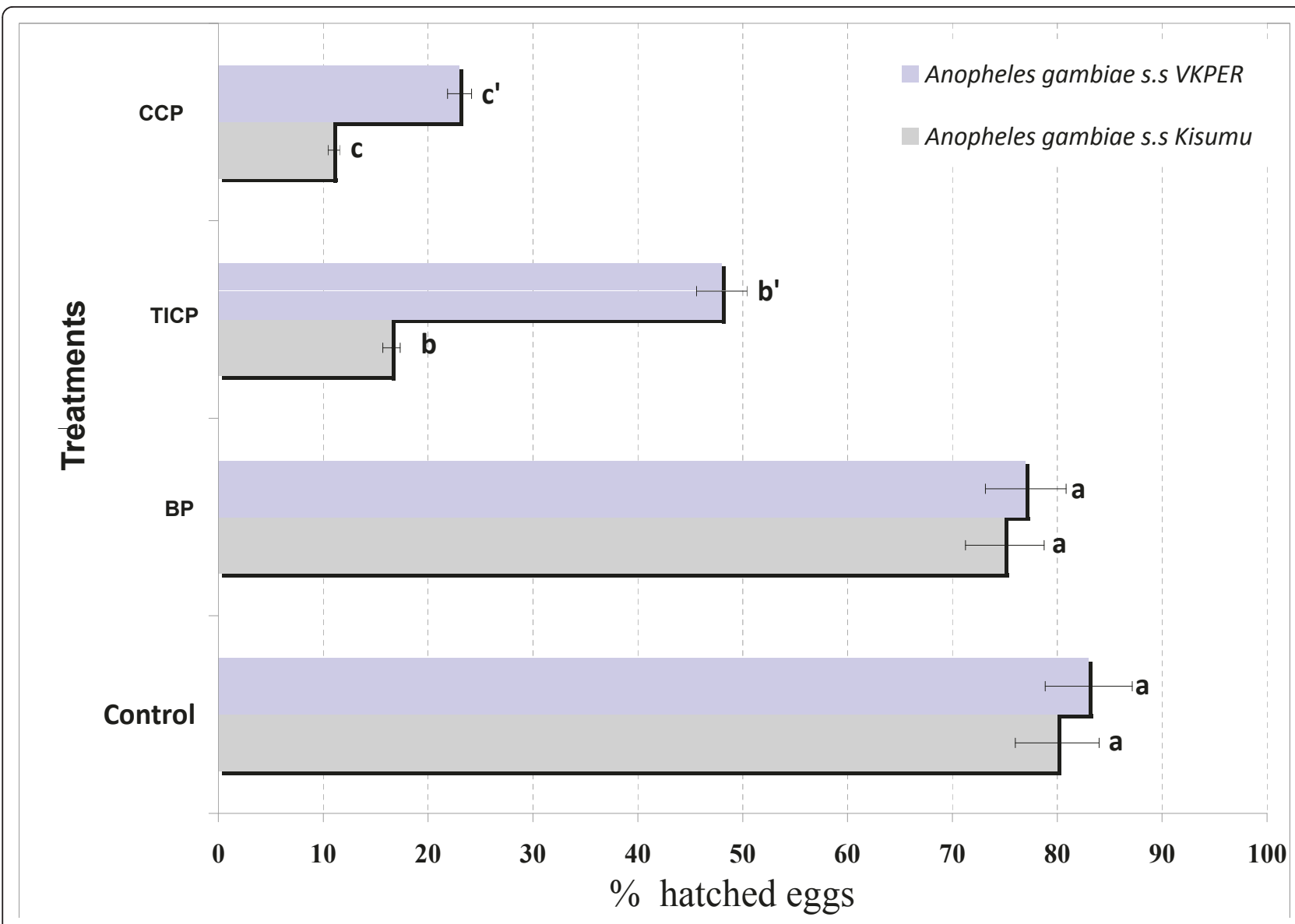

Figure 4 Percentage of eggs hatching of An. gambiae in water collected from breeding sites inside CCP program (in Parakou), TICP program (in N'Dali), BP program (in Banikoara) compared with distilled water (as control).

evidence on the implication of agricultural use of insecticides in the selection of resistance in the major malaria vectors. Our results agree with the work of Akogbeto et al [25] and confirm once again the impact of the extensive use of insecticides in cotton crop protection on the emergence of insecticide resistance in An. gambiae populations. Moreover, in CCP and TICP program, some farmers used insecticides belonging to the organophosphate classes. Ace-1R gene is the main resistance mechanism of An. gambiae s.l. to organophosphates and carbamates also. The present study, has shown that the ace-1R gene is present at low frequency (ranging from 0.01 to 0.09 ), but only in CCP and TICP program. However, previous field surveys on An. gambiae s.l. populations of South-Western

Burkina Faso by Djogbenou et al [14] in cotton fields showed that ace-1R gene was the main resistance mechanism in An. gambiae s.l.

However the National Malaria Control Program (NMCP) in Benin has started scaling up Long Lasting Insecticidal Nets (LLINs) and carbamate for Indoor
Residual Spraying (IRS) countrywide for malaria control. The challenge to find effective strategies to manage insecticide resistance in Anopheles gambiae remains a high priority and an urgent need particularly in Benin where pyrethroid resistance has been reported with a clear evidence in experimental huts of reduced efficacy of ITNs and IRS [39]. One of the strategies will be to remove pyrethroids from agricultural pest control and leave these classes of insecticides for public health purposes and promote other classes of insecticides such as Spinosad which does not show cross resistance to pyrethroids (i.e. the $k d r$ gene).

\section{Conclusions}

With the spread of $K d r$ allele frequency from CCP and TICP programmes, to reduce the emergence of insecticide resistance in An. gambiae population, African governments would be better advised to promote the BP cotton or genetically modified cotton such as $B t$ Cotton (Bacillus thurengiensis) which require lower pesticide than the cotton with CCP and TICP programme and 
$\mathrm{CCP}$

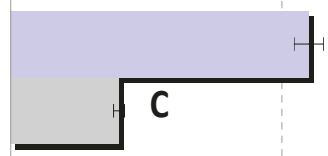

\section{$c^{\prime}$}

Anopheles gambiae s.S Kisumu

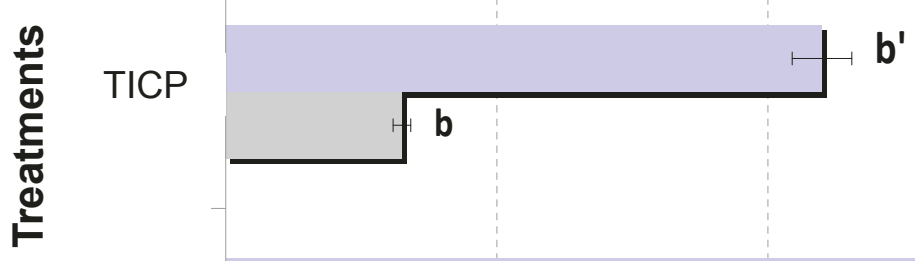

BP

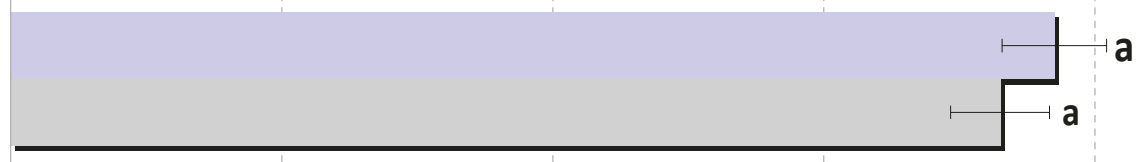

Control

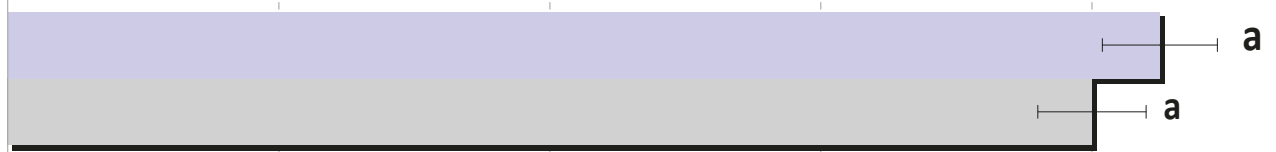

0

\section{$\%$ 1st instars larvae getting to pupae}

Figure 5 Percentage of emerging adults of An gambiae reared in water collected from breeding sites inside CCP program (in Parakou), TICP program (in N'Dali), BP program (in Banikoara) compared with distilled water (as control). - A: before treatments - B after treatments - Areas for CCP programs: Parakou; Kandi 1 and Banikoara1 - Areas for TICP programs: N'dali, Kandi 2 and Banikoara 2 • Areas for BP programs: Kandi 3 and Banikoara 3

would permit to suppress the massive use of pyrethroid insecticides.

\section{Acknowledgements}

This work was financially supported by the French government (Corus 6015 project). I am grateful to CREC's staff particularly Sebastien Koudenoukpe and Géraldo Houndéton for technical assistance during laboratory bioassays and field collections.

\section{Author details}

${ }^{1}$ Centre de Recherche Entomologique de Cotonou (CREC), 06 BP 2604 Cotonou, République du Bénin. ${ }^{2}$ Centre de Coopération Internationale en Recherche Agronomique pour le Développement, CIRAD-UR Hortsys, 34980 Montpellier, France. ${ }^{3}$ Institut de Recherche pour le Développement (IRD)/ Laboratoire de lutte contre les Insectes Nuisibles (LIN), Centre Collaborateur OMS 911 Ave Agropolis BP 64501, 34394 Montpellier Cedex 5 France. ${ }^{4}$ Institut de Recherche pour le Développement (IRD)/Centre de Recherche Entomologique de Cotonou (CREC), 01 BP 4414 RP Cotonou, République du Bénin. ${ }^{5}$ Institut de Recherche en Science de la Santé (IRSS)/Centre Muraz, BP

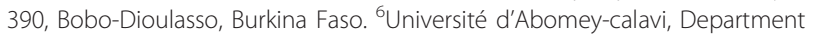
of geography, B.P. 526 Abomey-Calavi, 01 BP 526 Cotonou, Benin. 'Université de Lomé, Faculté de Sciences et Techniques, Lomé, Togo.

\section{Authors' contributions}

AY carried out field experiments, collected, analysed, interpreted data and wrote the manuscript. TM, GP reviewed the manuscript and contributed to the design of the study and substantially helped in drafting the manuscript, and revised the manuscript. FC, LD, RD, IG and MB contributed to the design of the study. AA helped in drafting and reviewing the manuscript and RA helped with the activities. TM, MA conceived and designed the study, supervised fields and laboratory procedures, and reads the manuscripts. All authors read and approved the final manuscript.

\section{Competing interests}

The authors declare that they have no competing interests.

Received: 6 December 2010 Accepted: 13 April 2011

Published: 13 April 2011

\section{References}

1. WHO: World Malaria Report 2009. World Health Organzation, Geneva; 2009.

2. Ministère de la santé: Annuaire des statistiques sanitaires 2006. Cotonou; 2009

3. Reimer L, Fondjo E, Patchoke S, Diallo B, Lee YNg, Ndjemai HM, Atangana J, Traore SF, Lanzaro G, Cornel AJ: Relationship between $k d r$ mutation and resistance to pyrethroid and DDT insecticides in natural populations of Anopheles gambiae. J Med Entomol 2008, 45:260-266.

4. Ramphul U, Boase T, Bass C, Okedi LM, Donnelly MJ, Muller P: Insecticide resistance and its association with target-site mutations in natural populations of Anopheles gambiae from eastern Uganda. Trans $R \mathrm{SOC}$ Trop Med Hyg 2009, 103:1121-1126.

5. Chandre F, Darrier F, Manga L, Akogbeto M, Faye O, Mouchet J, Guillet P: Status of pyrethroid resistance in Anopheles gambiae sensu lato. Bull World Health Organ 1999, 77:230-234. 
6. Santolamazza F, Calzetta M, Etang J, Barrese E, Dia I, Caccone A, Donnelly MJ, Petrarca V, Simard F, Pinto J, Torre A: Distribution of knockdown resistance mutations in Anopheles gambiae molecular forms in west and west-central Africa. Malar J 2008, 7:74.

7. Djènontin $A$, Sahabi $B$, Moiroux $N$, Henry MC, Bousari $O$, Chabi J, Ossè $R$, Koudénoukpo S, Corbel V, Akogbéto M, Chandre F: Culicidae diversity, malaria transmission and insecticide resistance alleles in malaria vectors in Ouidah Kpomasse-Tori district from Benin (West Africa): A preintervention study. Parasit Vectors 2010, 3:83.

8. Vulule JM, Beach RF, Atieli FK, Mcallister JC, Brogdon WG, Roberts JM, Mwangi RW, Hawley WA: Elevated oxidase and esterase levels associated with permethrin tolerance in Anopheles gambiae from Kenyan villages using permethrin impregnated nets. Med Vet Entomol 1999, 13:239-244.

9. Elissa N, Mouchet J, Rivière F, Meunier JY, Yao K: Resistance of Anopheles gambiae s.s. to pyrethroids in Côte d'Ivoire. Ann Soc Belge Méd Trop 1993, 73:291-294.

10. Akogbéto M, Yakoubou S: Résistance des vecteurs du paludisme vis-à-vis des pyréthrinoïdes utilisés pour l'imprégnation des moustiquaires au Bénin, Afrique de l'Ouest. Bull Soc Pathol Exot 1999, 92:123-130.

11. Yadouleton AW, Asidi A, Rousseau FD, Braïma J, Agossou CD, Akogbeto MC: Development of vegetable farming: a cause of the emergence of insecticide resistance in populations of Anopheles gambiae in urban areas of Benin. Malar J 2009, 8:103.

12. Corbel V, N'Guessan R, Brengues C, Chandre F, Djogbenou L, Martin T, Akogbeto M, Hougard JM, Rowland M: Multiple insecticide resistance mechanisms in Anopheles gambiae and Culex quinquefasciatus from Benin, West Africa. Acta Trop 2007, 101:207-216.

13. N'Guessan R, Corbel V, Akogbeto M, Rowland M: Reduced efficacy of insecticidetreated nets and indoor residual spraying for malaria control in pyrethroid resistance area, Benin. Emerg infect diseases 2007, 13:199-206.

14. Djogbénou L, Dabire R, Diabate A, Kengne P, Akogbeto M, Hougard JM, Chandre F: Identification and Geographic Distribution of the Ace-1R Mutation in the Malaria Vector Anopheles gambiae in South-Western Burkina Faso, West Africa. Am J trop med hyg 2008, 78:298-302.

15. Czeher C, Labbo R, Arzika I, Duchemin JB: Evidence of increasing Leu-Phe knockdown resistance mutation in Anopheles gambiae from Niger following a nationwide long-lasting insecticide-treated nets implementation. Malar J 2008, 7:189.

16. Diabate A, Baldet T, Chandre F, Guiguemde RT, Brengues C, Guillet P, Hemingway J, Hougard JM: First report of the kdr mutation in Anopheles gambiae M form from Burkina Faso, West Africa. Parassitologia 2002, 44:157-158.

17. Diabate $A$, Baldet $T$, Chandre F, Akogbéto M, Guiguemde RT, Darriet F, Brengues C, Guillet P, Hemingway J, Graham JS, Hougard JM: The role of agricultural use of insecticides in resistance to pyrethroids in Anopheles gambiae s.I in Burkina Faso. Am J Trop Med Hyg 2002, 67:617-622.

18. Fanello C, Petrarca V, Torre D, Santolamazza A, Dolo F, Coulibaly G, Alloueche MA, Curtis CG, Toure YT, Coluzzi M: The pyrethroid knock-down resistance gene in the Anopheles gambiae complex in Mali and further indication of incipient speciation within An. gambiae s.s. Insect Mol Biol 2003, 12:241-245.

19. Awolola TS, Brooke BD, Koekemoer LL, Coetzee M: Resistance of the malaria vector Anopheles gambiae s.s. to pyrethroid insecticides, in south-western Nigeria. Ann Trop Med Parasitol 2002, 96:849-852.

20. Hargreaves K, Koerkemoer LL, Brooke B, Hunt RH, Mthembu J, Coetzee M: Anopheles funestus resistant to pyrethroid insecticides in South Africa. Med Vet Entomol 2000, 14:181-189.

21. Etang J, Manga L, Chandre F, Guillet P, Fondjo E, Mimpfoundi R, Toto JC, Fontenille D: Insecticide susceptibility status of Anopheles gambiae s.I. (Diptera: Culicidae) in the Republic of Cameroon. J Med Entomol 2003, 40:491-497.

22. WABI: The cross-border integration of the cotton sub-sector. West African Borders and Integration Network. Coton et Fibres Tropicales 2003, 112:54-71.

23. N'Guessan F, Darriet P, Guillet P, Carnevalle M, Lamizana T, Corbel V, Chandre F: Resistance to carbosulfan in Anopheles gambiae base on reduced of acethylcholinesterase. Med vet Entomol 2003, 17:19-25.

24. Akogbéto M, Djouaka R, Gazard DA: Screening of pesticide residues in soil and water samples from agricultural settings. Malar J 2006, 5:22.
25. Akogbéto M, Djouaka R, Noukpo H: Use of agricultural insecticides in Benin. Bull Soc Pathol Exot 2005, 98:400-405.

26. Deguine JP, Ekukole G, Amiote P: La lutte étagée ciblée: un nouveau programme de protection insecticide en culture cotonnière au Cameroun. Coton et Fibres Tropicales 1993, 48:99-119.

27. Prudent $P$, Loko S, Deybe D, Vaissayre M: Factors limiting the adoption of IPM practices by cotton farmers in Benin: a participatory approach. Cambridge University Press 2006, 10:10-17.

28. WHO: World Malaria Report 2008. World Health Organzation, Geneva; 2008.

29. Scott JA, Brogdon WG, Collins FH: Identification of single specimens of the Anopheles gambiae complex by the polymerase chain reaction. Am J Trop Med Hyg 1993, 49:520-529.

30. Favia G, Torre D, Bagayoko M, Lanfrancotti M, Sagnon NF, Toure Y, Coluzzi M: Molecular identification of sympatric chromosomal forms of Anopheles gambiae and further evidence of their reproductive isolation. Insect Mol Biol 1997, 6:377-383.

31. Martinez TD, Chandre F, Williamson MS, Darriet F, Berge JB, Devonshire AL, Guillet P, Pasteur N, Pauron D: Molecular characterization of pyrethroid knockdown resistance $(k d r)$ in the major malaria vector Anopheles gambiae s.s.. Insect Mol Biol 1998, 7:179-184

32. Weill M, Malcolm C, Chandre, Mogensen K, Berthomieu A, Marquine M, Raymond $\mathrm{M}$ : The unique mutation in ace-1 giving high insecticide resistance is easily detectable in mosquito vectors. Insect Mol 2004, 9:1-7.

33. WHO: World Malaria Report 1998. World Health Organzation, Geneva; 1998

34. Finney DJ: Probit analysis. Cambridge University Press Cambridge; 1971

35. Raymond M, Rousset F: Genepop (version 1.2). A population genetics software exact tests and ecumenicism. Heredity J 1995, 86:248-249.

36. Henry MC, Assi SB, Rogier C, Dossou-Yovo J, Chandre F, Guillet P, Carnevale P: Protective Efficacy of Lambda-Cyhalothrin Treated Nets in Anopheles gambiae Pyrethroid Resistance areas of Cote d'ivoire. Am J Trop Med Hyg 2005, 73:859-864.

37. Hargreaves K, Koekemoer LL, Brooke BD, Hunt RH, Mthembu J, Coetzee M Anopheles funestus resistant to pyrethroid insecticides in South Africa. Med Vet Entomol 2000, 14:1-9.

38. Yadouleton AW, Padonou G, Asidi A, Moiroux N, Sahabi B, Corbel V, N'guessan R, Gbenou D, Yacoubou I, Kinde G, Akogbeto MC: Insecticide resistance status in Anopheles gambiae in southern Benin. Malar J 2010, 9:83.

39. Akogbéto MC, Padonou G, Gbénou D, Irish S, Yadouleton AW: Bendiocarb, a potential alternative against pyrethroid resistant Anopheles gambiae in Benin,West Africa. Malar J 2010, 9:204.

doi:10.1186/1756-3305-4-60

Cite this article as: Yadouleton et al:: Cotton pest management practices and the selection of pyrethroid resistance in Anopheles gambiae population in Northern Benin. Parasites \& Vectors 2011 4:60.

\section{Submit your next manuscript to BioMed Central and take full advantage of:}

- Convenient online submission

- Thorough peer review

- No space constraints or color figure charges

- Immediate publication on acceptance

- Inclusion in PubMed, CAS, Scopus and Google Scholar

- Research which is freely available for redistribution

Submit your manuscript at www.biomedcentral.com/submit
C Biomed Central 